\title{
Penilaian Kreativitas Anak melalui Metode Bermain
}

\author{
Julia Luly \\ Jurusan Pendidikan Guru Pendidikan Anak Usia Dini Fakultas Ilmu Pendidikan \\ Universitas Negeri Gorontalo \\ julia.luly06@gmail.com
}

\begin{tabular}{l} 
Info Artikel \\
\hline Sejarah Artikel: \\
Diterima (Juli) (2020) \\
Disetujui (Juli) (2020) \\
Dipublikasikan (Juli) 2020) \\
\hline Keywords: \\
Kreativitas; Metode \\
Bermain; Anak. \\
\hline
\end{tabular}

\begin{abstract}
Abstrak
Plastisin merupakan salah satu media pembelajaran yang digunakan untuk meningkatkan kreativitas anak. Selain melatih krativitas anak, bermain plastisin juga berfungsi untuk melatih motorik halus anak dan terdapat beberapa orang anak yang belum mampu membentuk menggunakan plastisin. Maka penelitian ini mengangkat masalah bagaimana peningkatan kreativitas anak melalui bermain plastisin. Penelitian ini bertujuan untuk mengetahui peningkatan kreativitas anak melalui metode bermain plastisin di TK Kartini Mopusi, Kecamatan Lolayan, Kabupaten Bolaang Mongondow. Teknik pengumpulan data dilakukan melalui observasi dan unjuk kerja. Metode analisis data yang digunakan adalah analisis deskriptif kualitatif. Subjek penelitian adalah anak-anak TK Kartini Mopusi, yang berjumlah 20 orang anak terdiri dari 9 orang anak laki-laki dan 11 anak perempuan. Pada TK Kartini Mopusi, Kecamatan Lolayan, Kabupaten Bolaang Mongondow yang berjumblah 20 orang anak, terdapat 8 orang anak yang belum berkembang, 5 orang anak yang mulai berkembang dan 7 orang anak yang sudah berkembang sesuai harapan.
\end{abstract}

\begin{abstract}
Plasticine is one of the learning media used to increase children's creativity. In addition to training the creativity of children, playing plasticine also serves to train the child's fine motor skills and there are some children who have not been able to form using plasticine. Therefore, this study raises the problem of how to increase children's creativity through playing plasticine. This study aims to determine the increase in creativity through playing plasticine method in Kartini Mopusi Kindergarten, Lolayan District, Bolaang Mongondow Regency. Data collection techniques are done through observation and performance. Data analysis method used is qualitative descriptive analysis. Subjects were Kartini Mopusi Kindergarten children, with 20 children consisting of 9 boys and 11 girls. In Kartini Mopusi Kindergarten, Lolayan Subdistrict, Bolaang Mongondow Regency, there were 20 children growing, 8 children were undeveloped, 5 children were developing and 7 children were developing as expected.
\end{abstract}




\section{Pendahuluan}

Pendidikan anak usia dini (PAUD) pada hakikatnya ialah pendidikan yang diselenggarakan dengan tujuan untuk memfasilitasi pertumbuhan dan perkembangan anak secara menyeluruh atau menekankan pada pengembangan seluruh aspek kepribadian anak. Oleh karena itu, PAUD memberi kesempatan pada anak untuk mengembangkan berbagai aspek, seperti kognitif, bahasa, sosial, emosi, fisik, dan motorik.

Di pendidikan formal seperti TK / RA atau yang setara terdapat 5 bidang pengembangan di dalam KTSP (Kurikulum Tingkat Satuan Pendidikan) yang terdapat dalam: 1) pengembangan pembiasaan yang mencakup perkembangan nilai - nilai agama dan moral serta sosial, emosional dan kemandirian. 2) Pengembangan kemampuan dasar mencakup perkembangan bahasa, fisikmotorik dan kognitif.

Dari kedua bidang pengembangan tersebut tujuannya antara lain; nilai - nilai agama dan moral dimana isi pembelajaran bertujuan menanamkan norma agama dan pembentukan akhlaq anak didik agar dapat berprilaku sesuai dengan norma yang berlaku di lingkungan tempat tinggalnya, selain norma agama perkembangan sosial emosional anak didik senantiasa dibimbing agar siswa dapat mengatur keadaan emosi dan bisa menjalankan kehidupannya sebagai mahluk sosial. Perkembangan bahasa juga diberikan di pendidikan PAUD formal dari kemampuan berbahasa verbal maupun nonverbal, dengan tujuan anak didik mampu memahami dan mengungkapkan pikiran dan perasaan yang ada pada anak didik. Perkembangan fisik anak juga diamati secara berkala dan berkesinambungan baik motorik halusnya ataupun motorik kasarnya, dengan tujuan kesehatan fisik jasmaninya dapat berkembang secara optimal. Selanjutnya mengamati perkembangan kognitif anak didik, yang berkaitan dengan perkembangan kognitif seperti baca tulis, mengenal angka, sains, konsep mengelompokkan, meningkatkan kreativitas, dll.

Kelima bidang pengembangan tersebut diberi stimulasi agar perkembangannya optimal sehingga anak akan mendapatkan ketrampilan hidupnya. Salah satu perkembangan kognitif di atas meningkatkan kreativitas sangatlah penting dalam kehidupan anak didik dan secara tidak langsung dapat meningkatkan prestasi belajar anak didik di tingkat pendidikan selanjutnya. Sebagian besar lembaga pendidikan 
selalu mengutamakan kecerdasan intlektual / IQ saja padahal kreativitas penting, sebab kreativitas dan intelegensi sama-sama berperan dalam prestasi belajar. Kreativitas yang tinggi dapat meningkatkan prestasi belajar. Kreativitas sangat dibutuhkan karena banyak permasalahan serta tantangan hidup yang menuntut kemampuan adaptasi secara kreatif dan kepiawaian dalam mencari pemecahan masalah yang imajinatif. Torrance (1959) dkk, menyimpulkan bahwa kelompok siswa yang kreativitasnya tinggi tidak beda dalam prestasi sekolah dengan siswa.

\section{Metode Penelitian}

Penelitian ini menggunakan metode penelitian kualitatif. Penelitian ini di laksanakan di TK Kartini Mopusu beralamat desa Mopusu, Kecamatan Lolayan, Kabupaten Bolaang mongondow, Provinsi Sulawesi Utara, Penelitian ini di laksanakan pada semester Lima, tahun ajaran 2018/2019 yaitu pada tanggal 5 Desember 2019. Adapun Subjek penelitian ini adalah anak usia 5-6 tahun di TK Kartini Mopusi, yang beralamat di Desa Mopusi, Kecamatan Lolayan, Kabupaten Bolaang Mongondow, Provinsi Sulawesi Utara, yang berjumlah 20 anak yang terdiri atas 9 orang laki-laki dan 11 perempuan. Prosedur Data penelitian ini adalah observasi dan unjuk kerja. Instrumen yang di gunakan dala m penelitian ini adalah penilaian kreativitas dan penilaian respon anak saat bermain plastisin. Teknik analisis yang di gunakan dalam penelitian ini adalah dengan menggunakan teknik analisis deskriptif kualitatif. Teknik ini menggunakan kata-kata untuk menjelaskan, menggambarkan kegiatan-kegiatan yang terjadi di dalam kelas saat kegiatan belajar mengajar berlangsung.

\section{Hasil Penelitian}

\section{Hasil}

Hasil penelitian dalam penelitian ini, akan ditempilkan hasil per siklus, yang mana setiap siklus terdiri dari tiga pertemuan, berikut hasil penelitian yang akan ditampilkan. 
Tabel 1 Hasil Tiap Pertemuan pada Siklus I
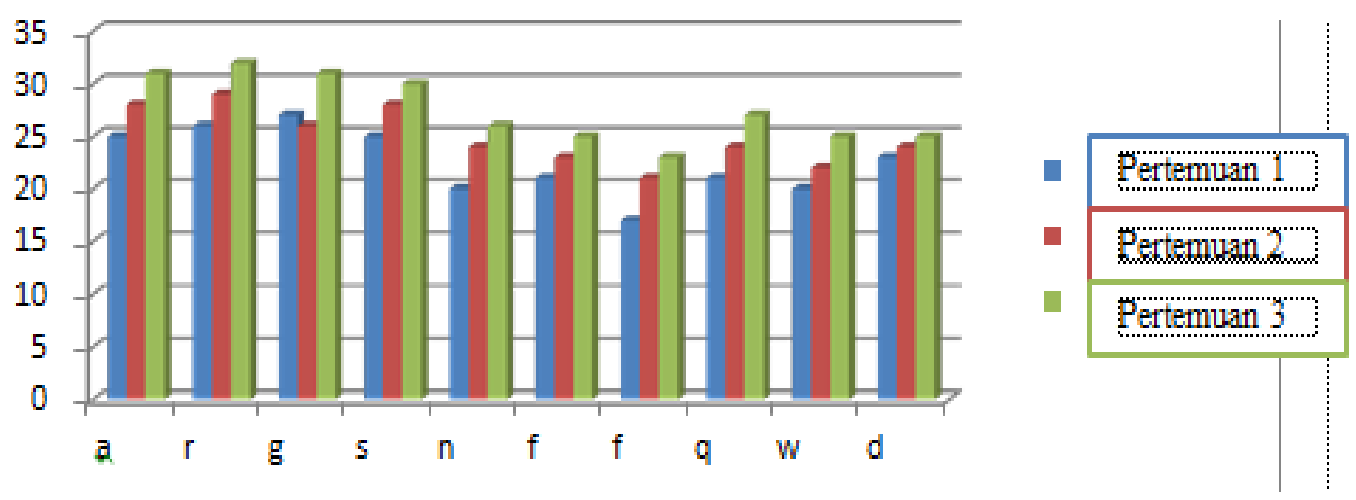

Dari table 1 diatas bahwa, aktivitas anak dalam berkreativitas menggunakan metode bremain setiap pertemuan selalu meningkat, dimana awalnya tiap anak merasa kaget dan belum terbiasa dengan metode bermain ini, sehingga pada saat melakukan refleksi peneliti dengan kolaborator yaitu guru bersama-sama menyusun rencana tindakan guna memasuki pertemuan kedua dan ketiga.

Selanjutnya peneliti akan menamilkan hasil pertemuan pada siklus II, adalah sebagai berikut:

Tabel 1 Hasil Tiap Pertemuan pada Siklus II
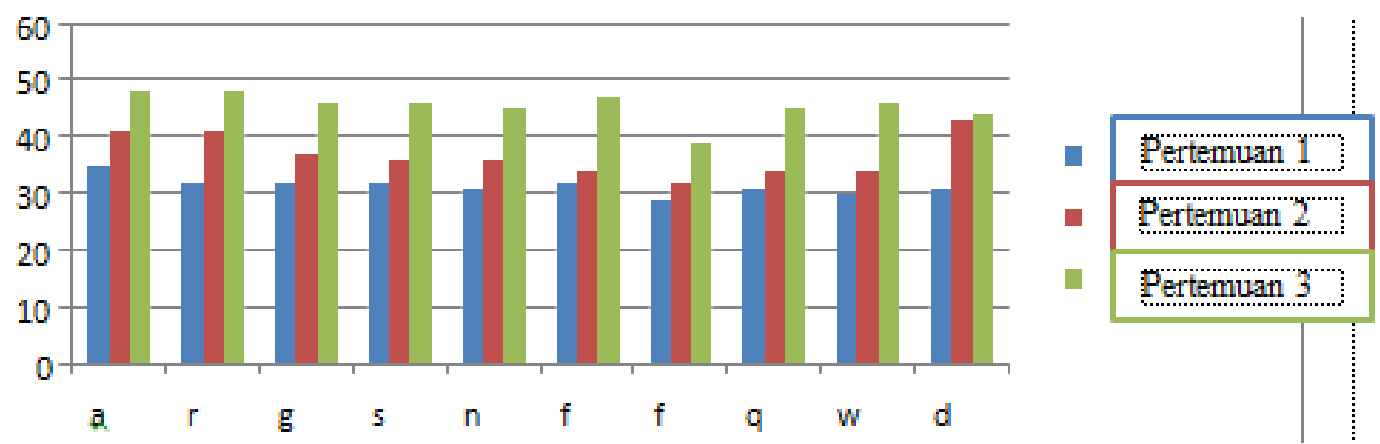

Pada siklus II anak merasa sangat senang melakukan berbagai macama kreasi hal ini dapat di lihat pada table 2. Dimana pertemuan pertema sampai pertemuan ketiga terus mengalami peningkatan. Pada siklus 2 ini anak melakukan kreativitas dengan menggunakan plastisin, dimana dengan melakukan aktivitas anak secara tidak sengaja melakukan percakapan baik sesame teman maupun dengan gurunya, sebut saja a dia sangat senang melakukan berabagai hal terlihat dari perolehan skor yang dia miliki, tidak heran jika a pandai dalam bercakpa-cakap dan sangat ramah serta berani dalam mengemukakan pendapat. 


\section{Diskusi}

Ditinjau dari berbagai aspek kehidupan, pengembangan kreativitas sangatlah penting. Banyak permasalahan serta tantangan hidup menuntut kemampuan adaptasi secara kreatif dan kepiawaian dalam mencari pemecahan masalah yang imajinatif. Kreativitas yang berkembang dengan baik akan melahirkan pola pikir yang solutif yaitu ketrampilan dalam mengenali permasalahan yang ada, serta kemampuan membuat perencanaanperencanaan dalam mencari pemecahan masalah.

Menurut Santrock, (2002) Kreativitas adalah kemampuan untuk melakukan sesuatu dengan cara-cara yang baru dan tidak biasaserta menemukan solusi yang unik dengan masalah-masalah yang Dihadapi.

Menurut Mayesty, (2009) mengatakan bahwa kreativitas adalah cara berfikir dan bertindak Atau menciptakan sesuatu yang Original Dan bernilai atau merguna bagi orang tersebut atau orang lain.

Galangher dalam Munandar, (1999) mengatakan bahwa kreativitas berhubungan dengan kemampuan untuk menciptakan sesuatu yang baru, yang belum ada sebelumnya.

Dari beberapa sumber di atas Dapat di simpulkan bahwa Kreativitas adalah kemampuan seseorang dalam menciptakan sesuatu yang baru sesuai dengan Imajinasi atau khayalan.

Tujuan pengembangan kreativitas pada anak. Menurut Nursisto, (1999), kemampuan belajar siswa jadi lebih baik jika kemampuan kreativitasnya juga ikut dilibatkan. Pada dasarnya semua siswa memiliki kreatif dalam dirinya yang harus dikembangkan agar hidup jadi semangat dan produktif. Kesadaran akan kemampuan kreativitas ini harus dilatih untuk memacu keberhasilan siswa demi menyongsong masa depan.

Hal ini sejalan dengan ungkapan Getzels, dkk dalam Nursisto, (1999) yang mengemukakan dalam achievement test, siswa yang memiliki IQ tinggi hasilnya sama bagusnya dengan siswa yang memiliki kretif tinggi. Ibarat pepatah tiada rotan akar pun jadi, maksudnya tiada IQ tinggi tapi punya kreativitastinggi akan sama manfaatnya. Seperti telah dijelaskan pengembangan kreativitas dapat dikembangkan dengan pusat 
anak (area) salah satu area yang dibutuhkan adalah area seni. Suhaenah, (1998) dalam Zaman, (2009) berpendapat bahwa sumber belajar adalah manusia, bahan, kejadian, peristiwa, setting, tehnik yang membangun, kondisi yang memberikan kemudahan bagi anak didik untukbelajar memperoleh pengetahuan, ketrampilan dan sikap.

Karena pembelajaran yang di sukai anak adalah melalui bermain maka metode bermain plastisin sangat tepat untuk langkah awal pembentukan kreativitas. Dengan media yang mudah dibentuk Peneliti mengambil plastisin sebagai salah satu media pembelajaran.

Dengan bermain plastisin ini, anak belajar meremas, menggilik, menipiskan dan merampingkannya, ia membangun konsep tentang benda, perubahannya dan sebab akibat yang ditimbulkannya. Ia melibatkan indra tubuhnya dalam dunianya, mengembangkan koordinasi tangan dan mata, mengenali kekekalan benda, dan mengeksplorasi konsep ruang dan waktu.

Berdasarkan hasil penelitian Terhadap kegiatan bermain plastisin pada TK Kartini Mopusi yang berjumblah 20 orang anak Untuk meningkatkan kreativitas anak. Peneliti melihat dari hasil bermain plastisin Anak yang belum berkembang sebanyak 8 orang. Mereka hanya bisa membentuk 1 buah saja. Anak yang mulai berkembang sebanyak 5 orang. Mereka bisa Membuat sebanyak 2 buah. Anak yang berkembang sesuai harapan sebanyak 7 orang. Mereka bisa membuat sebanyak 3 buah.Peneliti Juga melihat bahwa hasil respon anak terhadap kegiatan bermain plastisin.Anak yang aktif sebanyak 11 orang anak dan anak yang kurang aktif 9 orang anak.

\section{Simpulan}

Berdasarkan hasil penelitian Terhadap kegiatan bermain plastisin pada TK Kartini Mopusi yang berjumblah 20 orang anak Untuk meningkatkan kreativitas anak. Peneliti melihat dari hasil bermain plastisin Anak yang belum berkembang sebanyak 8 orang. Mereka hanya bisa membentuk 1 buah saja. Anak yang mulai berkembang sebanyak 5 orang. Mereka bisa Membuat sebanyak 2 buah. Anak yang berkembang sesuai harapan sebanyak 7 orang. Mereka bisa membuat sebanyak 3 buah. 
Peneliti Juga melihat bahwa hasil respon anak terhadap kegiatan bermain plastisin.Anak yang aktif sebanyak 11 orang anak dan anak yang kurang aktif 9 orang anak.

\section{Daftar Pustaka}

Badruzaman. (2007). Modul Teori Renang I. FPOK UPI Bandung

Mayesty, Mary. (1990). Creative Activities for Young Children 4th Ed : Play, Development, and Creativity. New York: Delmar Publisher Inc

Munandar, S.C. Utami. (2012). Pengembangan Kreativitas Anak Berbakat. Rineka Cipta. Jakarta.

Nursisto. 2000. Kiat Menggali Kreatvitas. Mitra Gama Widya: Yogyakarta

Rochaya, Siti. (2012). Peningkatan kreatifitas anak melalui bermain plastisin. Skripsi. PGPAUD Fakultas Keguruan dan Ilmu Pendidikan. Universitas Muhamadia Purwokerto

Santrock, John W. (2014). Psikologi Pendidikan. Jakarta: Salemba Humanika

Sudjiono, Yuliani Nuraini dan Sudjiono, Bambang. (2010). Bermain. Bermain Kreatif Berbasis Kecerdasan Jamak. PT Indeks, Jakarta 